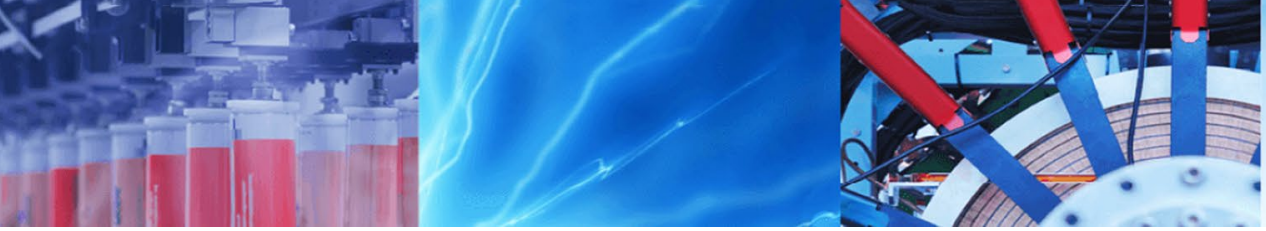

Research Article

\title{
Direct torque control of an induction motor fed by a Quasi Z-source inverter
}

\author{
Abdelhakim Derbane ${ }^{1} \cdot$ Bekheïra Tabbache $^{1} \cdot$ Aimad Ahriche $^{2}$
}

Received: 16 October 2019 / Accepted: 12 February 2020 / Published online: 18 February 2020

(c) Springer Nature Switzerland AG 2020

\begin{abstract}
This study presents an adapted direct torque control (DTC) of an induction motor fed by a Quasi Z-source power inverter. Indeed, the Quasi Z-source structure is introduced in the power inverter in order to boost the DC-Link voltage. For this, the boost control is mainly based on the shoot-through states of the power inverter which two power switches can be turned on at the same time. In this context, a switching table for DTC is developed to ensure an independent control of the flux and the torque of the induction motor and to boost the DC-Link voltage. Thus, the sampling time should be shared alternatively between the boost of the DC-Link voltage and the control of the electromagnetic torque. Consequently, the developed system reduces both the boost floor and the number of the used power switches. Moreover, it ensures a high-performance induction motor control. The validation results have been carried out to prove the effectiveness of the developed control.
\end{abstract}

Keywords Quasi Z-source inverter · Direct torque control · Shoot-through states · Induction motor

\section{Introduction}

Recently, three-phase conventional inverters are widely used in many industrial applications. This prominence is due to their simplicity and high performance. In fact, they consist only of six bi-directional power switches (Diodes, Isolated Gate Bipolar Transistors-IGBT), DC-Link and control circuits. However, in different applications such as supplying a three-phase induction motor, the DC-link requires high voltage values. Overall, an additional boost floor is needed to have an adequate voltage value which can lead to complex electrical circuits. Moreover, in these conventional power inverters, two switches of the same leg can't be turned-ON at the same time. Thus, to avoid the DC-Link short-circuit, a dead-time is necessary for safe operations [1,2]. These drawbacks can be overcome by inserting an impedance network to the power inverter. The new topology is called a Z-source structure which can give more merits to the whole system. The proposed solution provides the desired output DC voltage and produces a ride through during voltage sags $[3,4]$.

In terms of control, many papers address this issue [5]. Authors present different Pulse Width Modulation techniques applied to the Z-source inverter and comparative investigations of Simple boost control (SBC), Maximum boost control (MBC), and Maximum constant boost control (MCBC) [6].

In this paper, the developed system concerns the adaptation of the Direct Torque Control to an induction motor fed by a Quasi Z-source inverter.

In many industrial applications such as electric vehicles, photovoltaic energy, and Full cell systems, the power electronics converter system is composed of DC-DC converters to boost the output voltage and DC-AC converters to control the induction motor. These converters suffer from the number of power switches, weight, and cost of the

Bekheïra Tabbache, laid_tabache@yahoo.com | 'Department of Electrical Engineering, Polytechnic Military School, 16111 Algiers, Algeria. ${ }^{2}$ Department of Electrical Engineering and Automatic, University of Boumerdes, Boumerdes, Algeria. 
system $[7,8]$. So, to overcome these drawbacks, another solution can be envisaged by using a Z-source structure which consists of impedance networks (Inductances and capacitors) instead of the DC-DC converter. In this structure, the $D C-A C$ converter can ensure at the same time the voltage boost and the induction motor control operation modes $[9,10]$. However, in the Z-source structure, the same high voltage is applied to the two capacitors while in Quasi Z-source, the voltage applied on one of the two capacitors is lower, which requires a lower capacitor rating. Moreover, in the Quasi Z-source structure, the input current is continuous due to the inductance, which reduces input ripples.

In the other hand, to supply an induction motor by using a Quasi Z-source inverter, a specified control should be required. So, the two operation modes (boost task and the control of the induction motor) should be ensured.

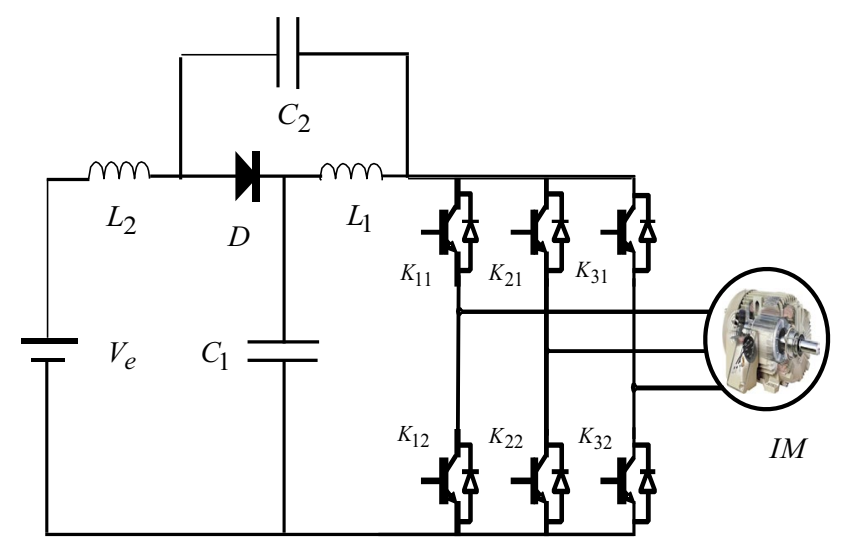

Fig. 1 Quasi Z-source Inverter structure
For this, the sampling time is divided between the boost and control operation modes. For the control operation modes, many control techniques can be used such as the Indirect Field Oriented Control (IFOC) [11]. In this context, regarding of the simplicity of implementation, this paper adopts the direct torque control [12]. For this, the adapted switching table is developed for both operation modes. In fact, an appropriate voltage vector should be chosen to ensure the load control while the boost task is ensured by the insertion of the null voltage vector to the three-phase inverter [13].

\section{Quasi Z-source structure}

Figure 1 shows a Quasi Z-source inverter structure. It consists of DC-link voltage, two inductances $\left(L_{1}, L_{2}\right)$, two capacitors $\left(C_{1}, C_{2}\right)$, a diode and three-phase inverter.

In this structure, two power switches (IGBT) of the same leg can operate at the same time to boost the DC-link voltage. In this context, shoot-through states are inserted during the zero states of the three-phase inverter. Moreover, the impedance network (inductances and capacitors) operates also as a filter that limits the current ripples during the shoot-through states [14].

Typically, a conventional three-phase power inverter has six active states and two zero states. However, the Quasi Z-source structure has six active states, two zero states and seven shout-through states such us given by Table 1. The shoot-through states are provided by the short-circuit of each power leg to give three states, two legs to obtain three states) and three legs provide one state of the Quasi Z-source three-phase inverter.
Table 1 Quasi Z-source inverter states

\begin{tabular}{lllllll}
\hline States & \multicolumn{2}{l}{ States of the switches } & & & \\
\cline { 2 - 6 } & K11 & K21 & K31 & K10 & K20 & K30 \\
\hline Active & 1 & 0 & 0 & 0 & 1 & 1 \\
& 1 & 1 & 0 & 0 & 0 & 1 \\
& 0 & 1 & 0 & 1 & 0 & 1 \\
& 0 & 1 & 1 & 1 & 0 & 0 \\
\multirow{3}{*}{ Zero } & 0 & 0 & 1 & 1 & 1 & 0 \\
& 1 & 0 & 1 & 0 & 1 & 0 \\
Shoot through & 1 & 1 & 1 & 0 & 0 & 0 \\
& 0 & 0 & 0 & 1 & 1 & 1 \\
& 1 & 0 & 0 & 1 & 0 & 0 \\
& 0 & 1 & 0 & 0 & 1 & 0 \\
& 0 & 0 & 1 & 0 & 0 & 1 \\
& 1 & 1 & 0 & 1 & 1 & 0 \\
& 1 & 0 & 1 & 1 & 0 & 1 \\
& 0 & 1 & 1 & 0 & 1 & 1 \\
\hline
\end{tabular}




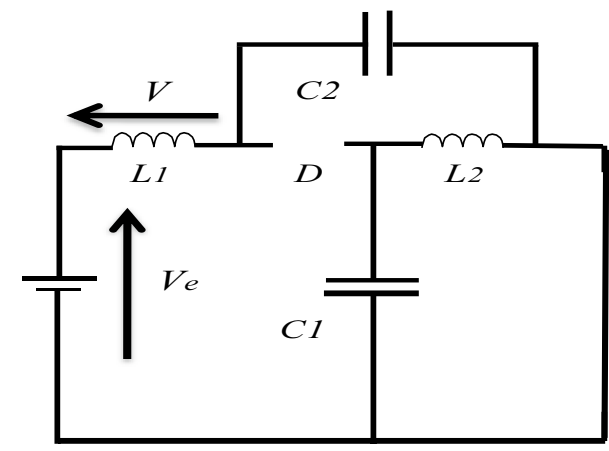

Fig. 2 Quasi Z-source shoot-through states equivalent circuit

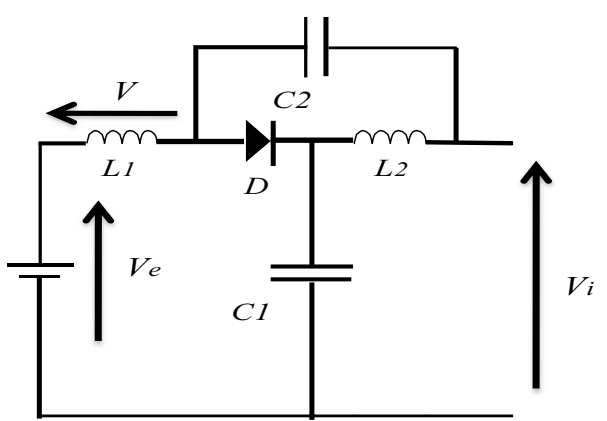

Fig. 3 Quasi Z-source inverter active states equivalent circuit

The role of the Quasi Z-source structure is to ensure, at the same time, a DC to AC conversion and boost the DC-link voltage like the step-up chopper. This operating mode can be analyzed by using an equivalent circuit, where both three-phase six-switch inverter and load are represented by one single switch $(\mathrm{K})$ in parallel with a single-phase load [15].

The Quasi Z-source network operates in two states: shoot-through states (Fig. 2) and no shoot-through states (Fig. 3).

In the no-shoot-through or actives states, the load is supplied by the DC-link voltage. However, in the shoot through or zero states, the Quasi Z-source structure increases the voltage across the capacitors.

The shoot-through states can be presented by the following equations:

$$
\left\{\begin{array}{l}
V_{L 1}=V_{C 2}-V_{e} \\
V_{L 2}=V_{C 1} \\
V_{i}=0
\end{array}\right.
$$

Active states can be expressed by the equations:
$\left\{\begin{array}{c}V_{L 1}=V_{e}-V_{C 1} \\ V_{L 2}=-V_{C 2} \\ V_{i}=V_{C 1}-V_{L 2} \\ V_{i}=V_{C 1}-V_{C 2}\end{array}\right.$

The average value of the inductance voltage $\left\langle V_{L}>\right.$ during this sampling time should be zero, and it is given by the following relation:

$$
\begin{aligned}
& \left\langle V_{L 1}\right\rangle=\left\langle V_{L 2}\right\rangle \\
& =\frac{T_{0} \times\left(V_{C 2}-V_{e}\right)+\left(T-T_{0}\right) \times\left(V_{e}-V_{C 1}\right)}{T}=0 \\
& \left\langle V_{C 2}\right\rangle=\frac{T_{0} \times V_{C 1}+\left(T-T_{0}\right) \times\left(-V_{C 2}\right)}{T}
\end{aligned}
$$

It is assumed that the duration of the shoot-through states is $T_{0}$ where $T$ represents the sampling time.

From the previous equation, $\mathrm{V}_{\mathrm{C} 1}$ and $\mathrm{V}_{\mathrm{C} 2}$ can be expressed by:

$V_{C 1}=\frac{\left(T-T_{0}\right)}{\left(T-2 \times T_{0}\right)} \times V_{e}$

$V_{C 2}=\frac{T_{0}}{\left(T-2 \times T_{0}\right)} \times V_{e}$

The expression of the maximum value of the voltage $V i$ is given as:

$V_{i}=V_{C 1}+V_{C 2}=\frac{T}{\left(T-2 \times T_{0}\right)} \times V_{e}$

Based on the above analysis, the Quasi Z-source inverter merits are better than in the Z-source structure. It can ensure the buck-boost modes and able to operate at shoot-through states. It is unnecessary to add a dead band into the control system, which reduces the output distortion. In addition, in Z-source, the same high voltage is applied to the two capacitors while in Quasi Z-source, the voltage on the capacitor $\left(C_{2}\right)$ is lower, which requires a lower capacitor rating. So, Z-source inverter has discontinuity input current in the boost mode, while in Quasi $Z$-source, the input current is continuous due to the inductor $L_{1}$, which reduces input stress [16].

\subsection{Impedance network sizing}

In Quasi Z-source topology, determining values of inductances $\left(L_{1}\right.$ and $\left.L_{2}\right)$ and capacitors $\left(C_{1}\right.$ and $\left.C_{2}\right)$ is an important and critical step that represents the key factor and has a great influence on the output voltage $V_{i}$. It allows 
increasing the DC input voltage and their values should be chosen with respect to the following equations [17]:

$L \geq \frac{d \times(1-d)}{\Delta i_{L} \times f_{m} \times(1-2 \times d)} \times V_{d c}$

$C \geq \frac{P \times d}{V_{d c} \times f_{m} \times \Delta V_{c}}$

where $d=\frac{T_{c c}}{T}$.

\section{Direct torque control of quasi Z-source inverter fed induction motor}

The main objective of the developed control is to ensure the DC-Link voltage boost and the control of the induction motor fed by a Quasi Z-source inverter. The boost task is ensured by an impedance network while the induction motor control is based on the direct torque control with hysteresis controllers. However, many control techniques such as backstepping and sliding mode can be used instead of the hysteresis controllers in order to improve the performance of the developed system $[18,19]$. In the literature, many works use backstepping and sliding mode techniques to control the stability and enhance the dynamics of the induction motors. So, the sliding mode is more suitable for systems with modeling uncertainties and variable parameters, or with the presence of large external disturbances. However, theses control techniques suffer from chattering phenomena and the choice of the gains $[20,21]$.

\subsection{Direct torque control principle}

Direct Torque Control is based on the selection of a voltage vector to control flux and torque values using hysteresis controllers [22].

Figure 4 shows the direct torque control scheme in which the control sequences are applied to the power switches. The control sequence is provided by the switching table to select the output voltage of the inverter $[23,24]$.

The stator flux in the induction motor is given in the stationary reference frame $(\alpha, \beta)$ by $[25]$ :
Fig. 4 Direct torque control scheme

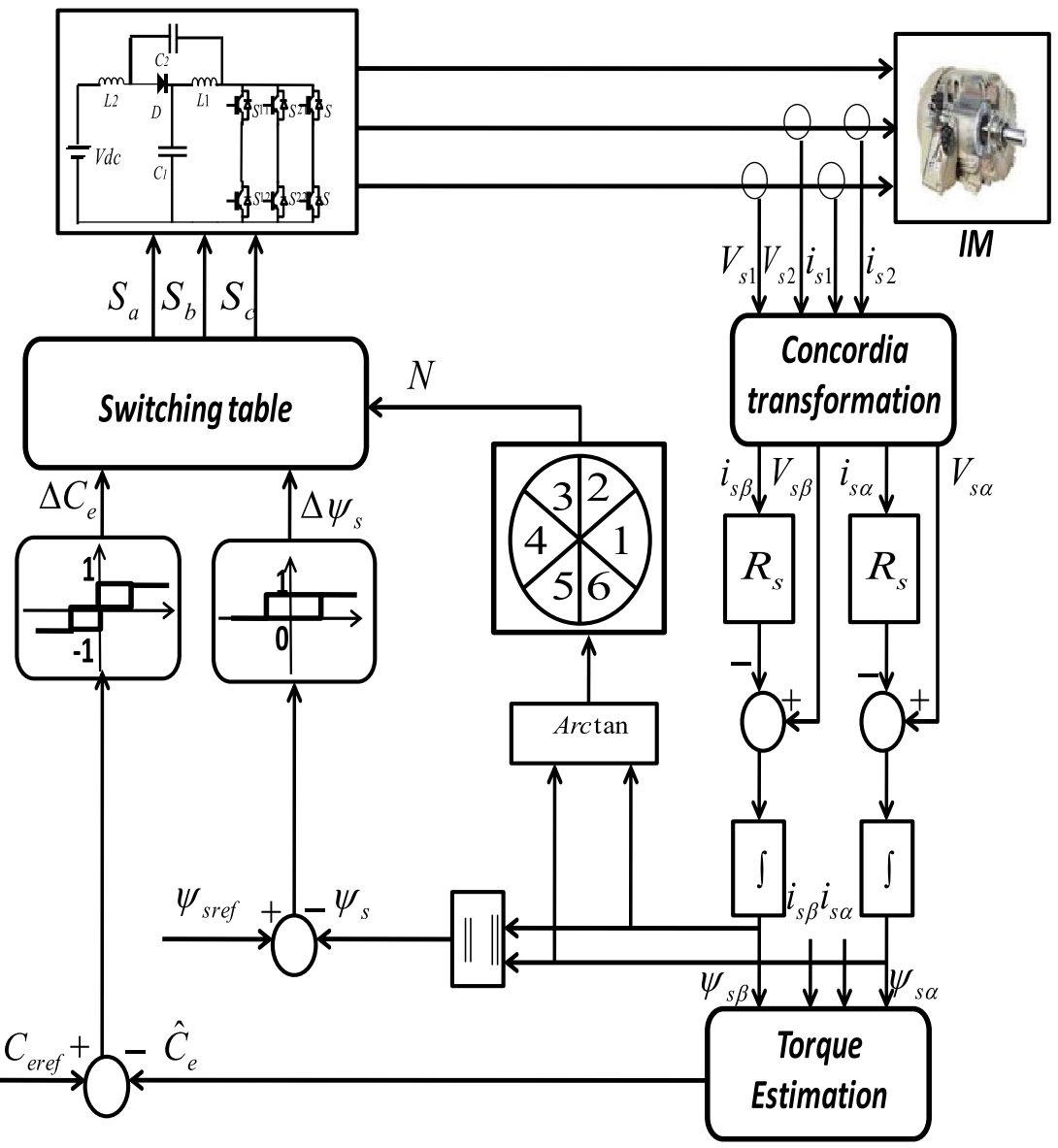


$\bar{V}_{s}=R_{s} \bar{T}_{s}+\frac{d \bar{\phi}_{s}}{d t}$

With: $\bar{\varphi}_{\mathrm{s}}=\int_{0}^{\mathrm{t}}\left(\overline{\mathrm{V}}_{\mathrm{s}}-\mathrm{R}_{\mathrm{s}} \overline{\mathrm{I}}_{\mathrm{s}}\right) \mathrm{dt}$

For high speeds, the voltage drop can be neglected due to the stator resistance.

$\bar{\varphi}_{\mathrm{s}}=\bar{\varphi}_{\mathrm{s} 0}+\int_{0}^{\mathrm{t}} \overline{\mathrm{V}}_{\mathrm{s}} \mathrm{dt}$

During each sampling time, the voltage vector to be applied is constant [26]:

$\Delta \bar{\varphi}_{\mathrm{s}}=\overline{\mathrm{V}}_{\mathrm{s}} \mathrm{Te}$

The error of the stator flux $\Delta \bar{\varphi}_{s}$ is linear with the voltage stator vector for a constant sampling time.

The stator flux amplitude is kept in the hysteresis band around its reference. The rotor flux amplitude will also be approximately constant when the flux is established in the motor. The flux estimation can be carried out based on current and voltage measurements [27].

The torque is the vector product of the stator and rotor flux vectors according to the equation:

$\Gamma_{\mathrm{e}}=\mathrm{K}\left(\bar{\varphi}_{\mathrm{s}} \times \bar{\varphi}_{\mathrm{r}}^{\prime}\right)=\mathrm{K} \bar{\varphi}_{\mathrm{s}} \bar{\varphi}_{\mathrm{r}}^{\prime} \sin \theta_{\mathrm{sr}}$

$$
\begin{gathered}
\text { Or: } K=p \frac{M}{L_{s} L_{r}} . \\
\left\{\begin{array}{l}
\mathrm{V}_{s \alpha}=r_{s \alpha} i_{s \alpha}+\frac{d \varphi_{s \alpha}}{d t} \\
\mathrm{~V}_{s \beta}=r_{s \beta} i_{s \beta}+\frac{d \varphi_{s \beta}}{d t}
\end{array}\right.
\end{gathered}
$$

The stator flux is expressed by:

$$
\left\{\begin{array}{l}
\varphi_{s \alpha}=\int_{0}^{t}\left(V_{s \alpha}-r_{s} i_{s \alpha}\right) d t \\
\varphi_{s \beta}=\int_{0}^{t}\left(V_{s \beta}-r_{s} i_{s \beta}\right) d t
\end{array}\right.
$$

In Concordia transformation, voltages $\left(\mathrm{V}_{\mathrm{s} \alpha}, \mathrm{V}_{\mathrm{s} \beta}\right)$ are obtained from the following equations:

$\bar{V}_{s}=\mathrm{V}_{s \alpha}+j \mathrm{~V}_{s \beta}$

Figure 5 shows the voltage vectors of the three-phase inverter representation.

$$
\left\{\begin{array}{l}
\mathrm{v}_{\mathrm{s \alpha}}=\sqrt{\frac{2}{3}} V_{d c}\left(S_{a}-\frac{1}{2}\left(S_{b}+S_{c}\right)\right) \\
\mathrm{v}_{s \beta}=\frac{1}{\sqrt{2}} V_{d c}\left(S_{b}-S_{c}\right)
\end{array}\right.
$$

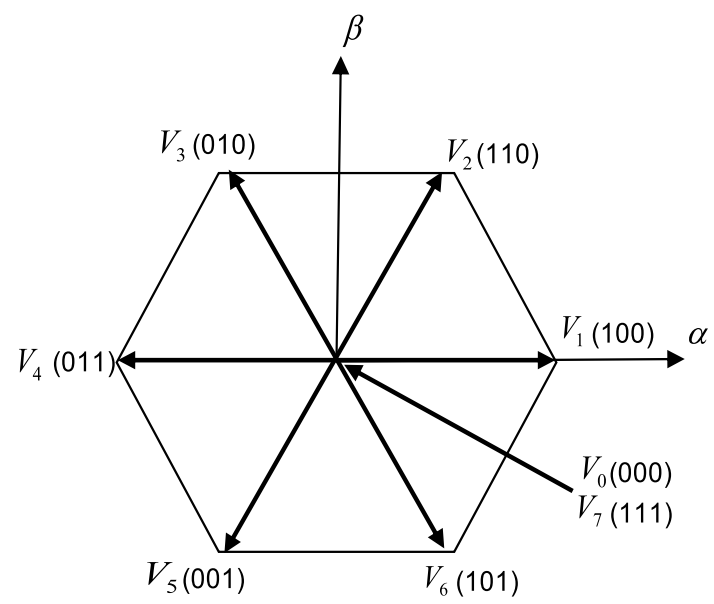

Fig. 5 Voltage vectors representation

The current components $\left(i_{s \alpha}, i_{s \beta}\right)$ in Cocordia fram are calculated by the phase currents $i_{a}, i_{b}, i_{c}[28]$ :

$\bar{l}_{s}=\mathrm{i}_{s \alpha}+j \mathrm{i}_{s \beta}$

$\left\{\begin{array}{l}\mathrm{i}_{\mathrm{s \alpha}}=\sqrt{\frac{2}{3}} i_{a} \\ \mathrm{i}_{\mathrm{s} \beta}=\frac{1}{\sqrt{2}}\left(i_{b}-i_{c}\right)\end{array}\right.$

The flux amplitude and angle are obtained by:

$\hat{\varphi}_{\mathrm{S}}=\sqrt{\hat{\varphi}_{\mathrm{S \alpha}}^{2}+\hat{\varphi}_{\mathrm{S} \beta}^{2}}$

$\theta_{s r}=\operatorname{arctg} \frac{\varphi_{s \beta}}{\varphi_{s \alpha}}$

The number of the flux sector is detected by the angle $\theta_{\text {sr }}$ and the stator components (Fig. 6) $[29,30]$.

Table 2 presents the switching table with non-active voltage vectors.

\subsection{DTC-based Shoot-through control}

In the developed control of the Quasi Z-source inverter, the shoot-through vector is inserted in zero states of the three-phase inverter. However, the duration of the zero states $\left(\mathrm{V}_{0}\right.$ or $\left.\mathrm{V}_{7}\right)$ can't be enough to boost the DC-Link voltage. Indeed, the control sequences are applied during a modulation period Tm such as [31]:

$\mathrm{T}_{\mathrm{m}}=\mathrm{K} \times \mathrm{T}_{\mathrm{e}}$

$\mathrm{K}$ : is an integer to be determined. 


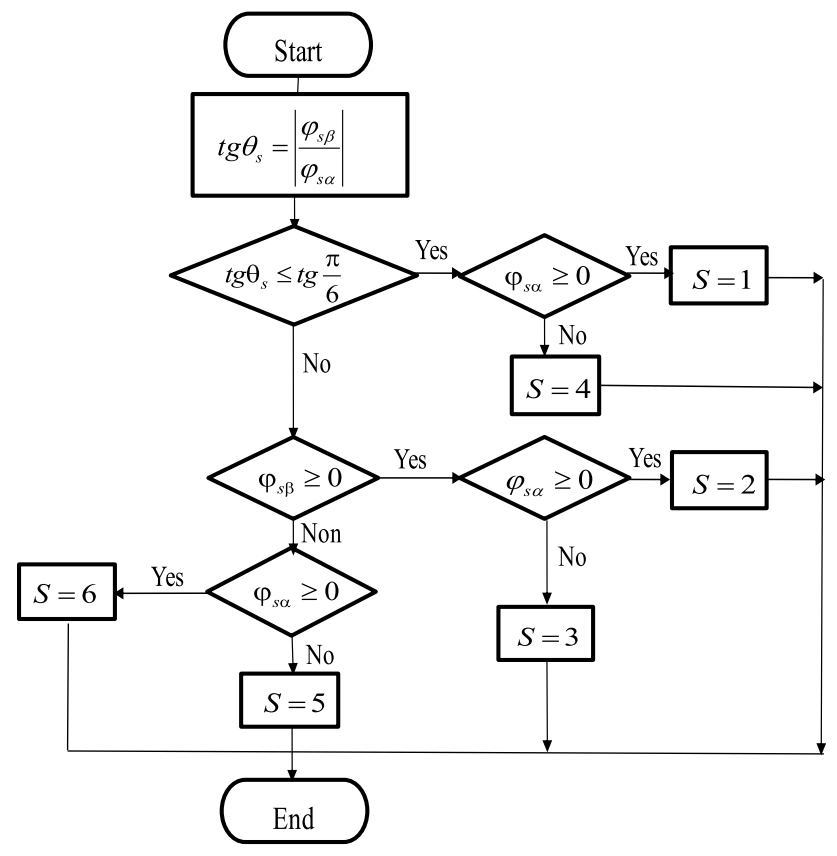

Fig. 6 Sectors detection

The insertion of the shoot-through state of the power leg inverter is performed by:

$\mathrm{T}_{\%}=\mathrm{d} \times \mathrm{T}_{\mathrm{m}}$

With: $0 \leq \mathrm{d} \leq 100 \%$.

During the remaining time $\left((1-d) T_{m}\right)$ the direct torque control is applied (Fig. 7).

Where $\mathrm{T}_{\text {DTC }}=(1-\mathrm{d})$.Tm is the DTC time and $\mathrm{T}_{\mathrm{ST}}=\mathrm{d} \mathrm{Tm}$ is the shoot-through time.

The duty ratio " $\mathrm{d}$ " is chosen to increase the DC-bus voltage by keeping the performance of the direct torque control in terms of flux and torque ripples. For this, the control time $\left(T_{m}\right)$ is shared between the DC-bus voltage control and the DTC strategy. Nevertheless, if the duty ratio is relatively small which means a sufficient application time of the DTC strategy $\mathrm{T}_{\text {DTC }}$ then the performance of the direct torque control can not be affected. Hence, the shoot through the duration $\mathrm{T}_{\mathrm{ST}}$ should be determined in order to regulate the DC-bus Voltage.

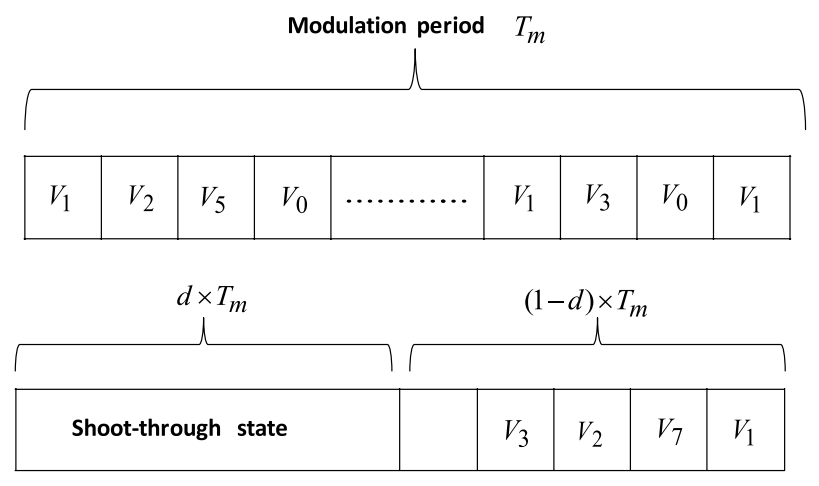

Fig. 7 Shoot-through states application

Table 3 DTC Quasi Z-source switching table

\begin{tabular}{|c|c|c|c|c|c|c|c|}
\hline \multicolumn{2}{|c|}{ Sector } & $\mathrm{N}=1$ & $\mathrm{~N}=\mathbf{2}$ & $\mathbf{N}=\mathbf{3}$ & $N=4$ & $N=5$ & $N=6$ \\
\hline \multirow{3}{*}{$\pi^{\pi}$} & $\mathrm{C}_{\mathrm{T}}=1$ & & & & & & \\
\hline & $\mathrm{C}_{\mathrm{T}}=0$ & & & & & & \\
\hline & $C_{T}=-1$ & & & & & & \\
\hline \multirow{3}{*}{$\prod^{\pi}$} & $\mathrm{C}_{\mathrm{T}}=1$ & & & & & & \\
\hline & $\mathrm{C}_{\mathrm{T}}=0$ & & & & & & \\
\hline & $C_{T}=-1$ & & & & & & \\
\hline
\end{tabular}

The switching table of the direct torque control for Quasi Z-source inverter is shown in Table 3. It summarizes the insertion of the active and shoots through states.

$\mathrm{V}_{\mathrm{ST}}$ : Represents the application of the shoot-through states. To increase the duration of the shoot-through the voltage vector $\mathrm{V}_{0}$ can be replaced by $\mathrm{V}_{7}$. DC bus control.

\subsection{DC bus regulation}

The DC bus voltage can be controlled by using both voltages across the capacitor ( $\mathrm{Vc}$ ) and across the input of the inverter (Vi) [32]. Regarding simplicity and effectiveness,
Table 2 DTC switching table

\begin{tabular}{|c|c|c|c|c|c|c|c|}
\hline \multirow[t]{2}{*}{ Flux } & \multirow[t]{2}{*}{ Torque } & \multicolumn{6}{|l|}{ Sector } \\
\hline & & 1 & 2 & 3 & 4 & 5 & 6 \\
\hline \multirow[t]{2}{*}{$S_{\varphi s}=1$} & $S_{\varphi s}=1$ & $V_{2}(1,1,0)$ & $V_{3}(0,1,0)$ & $V_{4}(0,1,1)$ & $V_{5}(0,0,1)$ & $V_{6}(1,0,1)$ & $V_{1}(1,0,0)$ \\
\hline & $S_{\varphi s}=0$ & $V_{7}(1,1,1)$ & $V_{0}(0,0,0)$ & $V_{7}(1,1,1)$ & $V_{0}(0,0,0)$ & $V_{7}(1,1,1)$ & $V_{0}(0,0,0)$ \\
\hline \multirow[t]{2}{*}{$S_{\varphi s}=0$} & $S_{\varphi s}=1$ & $V_{3}(0,1,0)$ & $V_{4}(0,1,1)$ & $V_{5}(0,0,1)$ & $V_{6}(1,0,1)$ & $V_{1}(1,0,0)$ & $V_{2}(1,1,0)$ \\
\hline & $S_{\varphi s}=0$ & $\mathrm{~V}_{0}(0,0,0)$ & $V_{7}(1,1,1)$ & $V_{0}(0,0,0)$ & $V_{7}(1,1,1)$ & $\mathrm{V}_{0}(0,0,0)$ & $V_{7}(1,1,1)$ \\
\hline
\end{tabular}




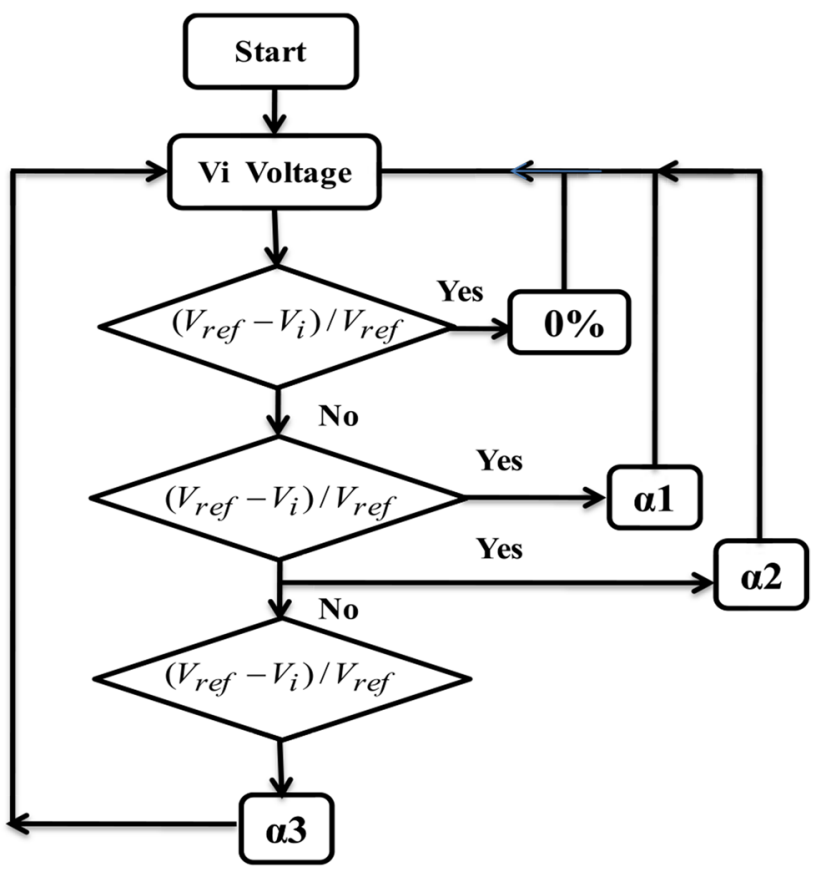

Fig. 8 Regulation algorithm of the DC-Link

this paper deals with a hysteresis controller to ensure enough shoot-through time and DC bus voltage $\left(\mathrm{V}_{\mathrm{i}}\right)$. The flowchart of this algorithm is shown in Fig. 8.

The decision is divided into four steps:

For this we define $\varepsilon$ as: $\varepsilon=\frac{v_{\text {ref }}-v_{i}}{V_{\text {ref }}}$.

If $\varepsilon$ is negligible, no shoot-through is applied.

Else if $\varepsilon$ has a small value, a 1 of shoot-through is applied.

Else if $\varepsilon$ has a medium value, $a 2$ of shoot-through is applied, else the maximum shoot-through (a3) is applied.

\section{Validation results}

The obtained results have been carried out by mean of an induction motor associated with an impedance network-based inverter, in which the parameters are given in the "Appendix". For this, the sampling time of the control has been divided between the boost process in order to insert the shoot-through states and the direct torque control for the induction motor.

In Fig. 9, it can be shown both of DC-Link voltage (Vdc) before and after boosting (Vi). Figure 10 presents the line to line voltage (Vab) applied to the induction motor.

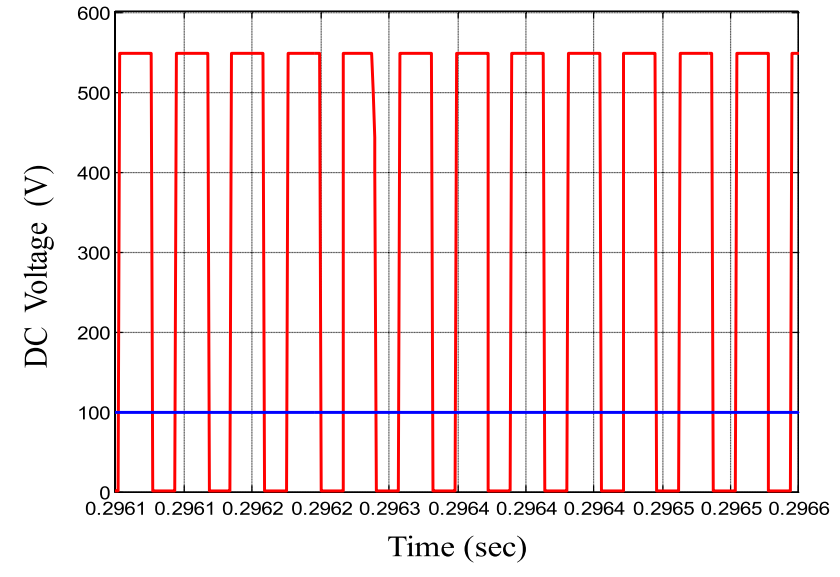

Fig. 9 DC-Link voltage Vi and reference voltage (Vdc)

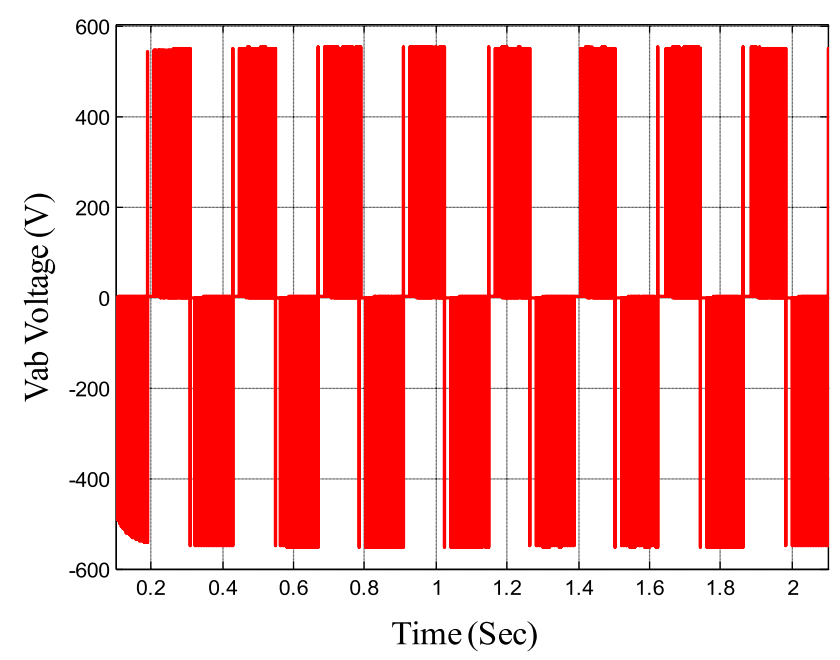

Fig. 10 Line to line voltage Vab

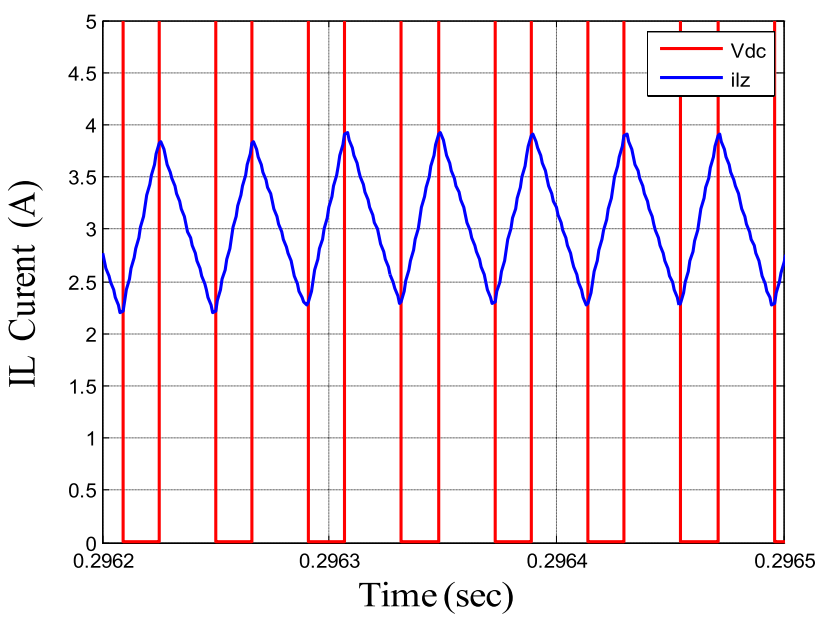

Fig. 11 Inductance current $\mathrm{I}_{\mathrm{I}}$ 


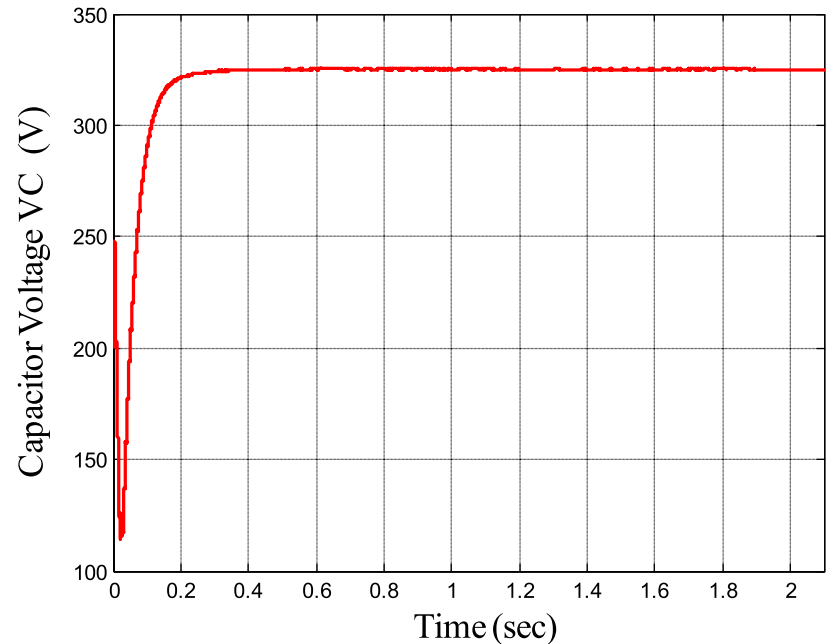

Fig. 12 Capacitor voltage $\mathrm{V}_{\mathrm{cz}}$

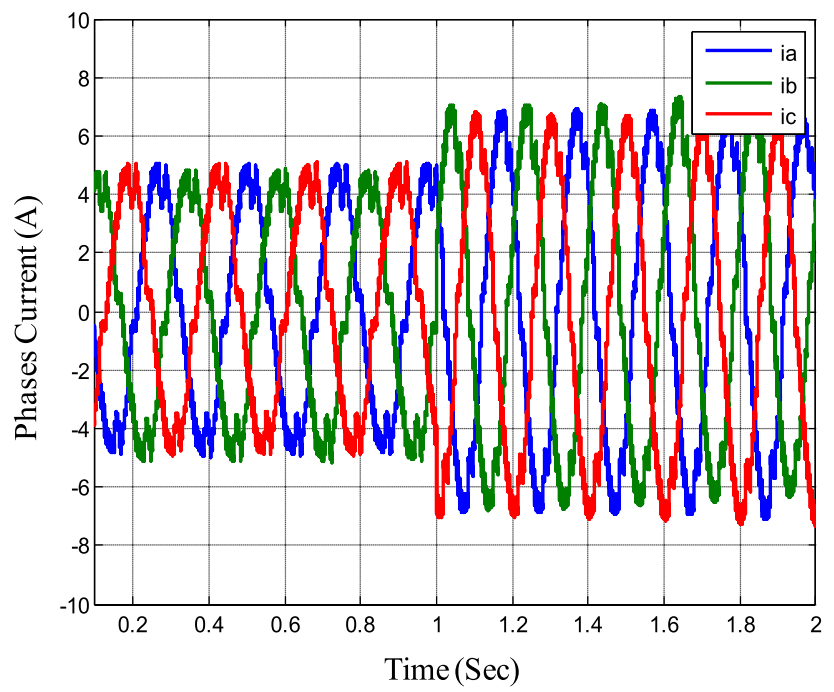

Fig. 13 Phase currents ia, ib and ic

Figures 11 and 12 show respectively the inductance current (Ilz) and the voltage across the capacitor (Vcz).

Figure 13 shows the absorbed sinusoidal current which proves the performance of the developed direct torque control.

Figures 14 and 15 show respectively the electromagnetic torque and speed responses.

Figure 16 shows the trajectory of the stator flux.

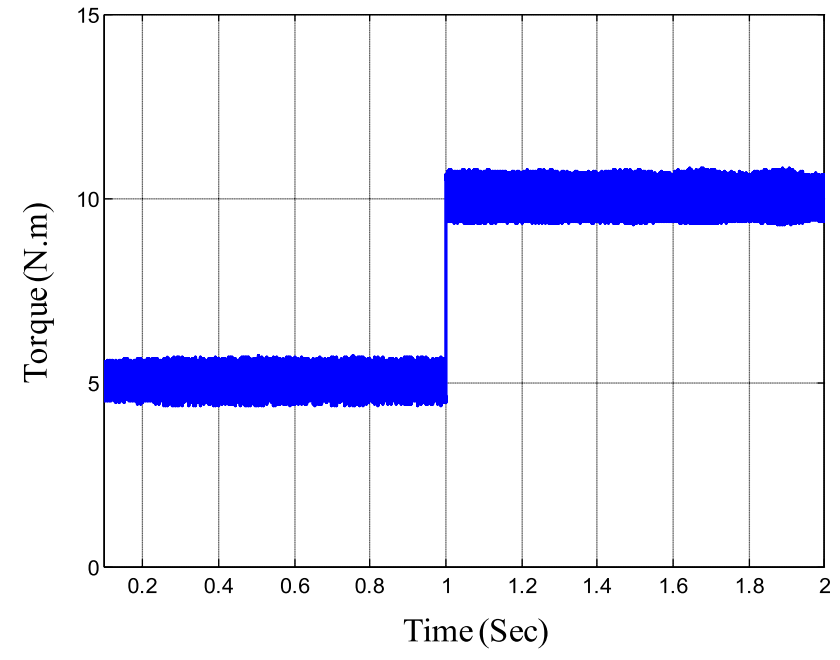

Fig. 14 Induction motor Torque

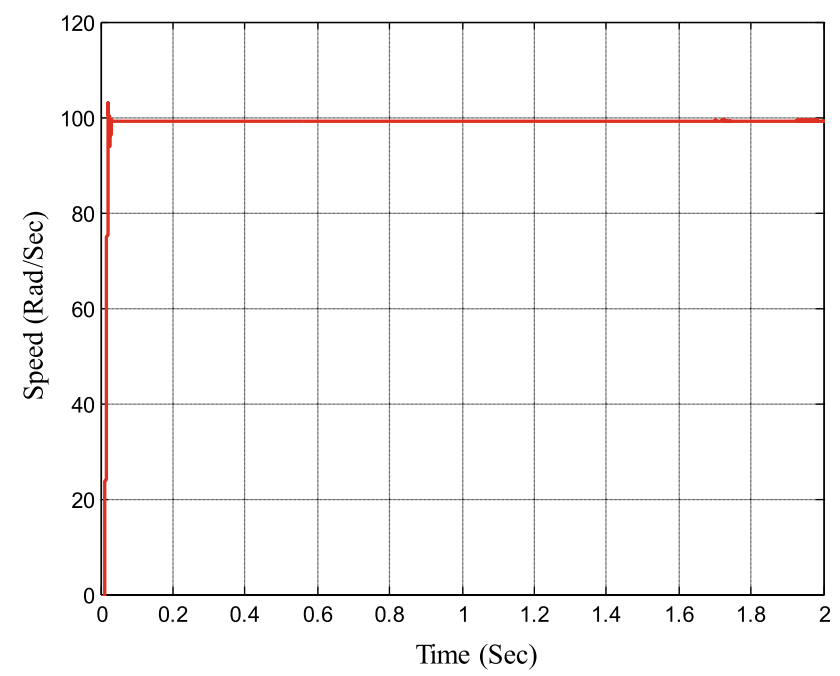

Fig. 15 Speed response

\section{Results discussion}

In the boost control mode, the DC input voltage is amplified with an elevation gain of $\mathrm{G}=5.5$ as shown in Fig. 9 . So, the impedance network (inductances and capacitors) ensures the operation of the DC/DC converter in a conventional system and therefore reduces the number of power switches in the developed system. Moreover, as given by Fig. 11, it can be seen that the inductance current ripples are reduced in the Quasi Z-source inverter compared with the Z-source structure [33]. For this, during the shoot-through states, the current $i_{L}$ is increased, and the two inductances are fully charged, while during the active states the current $i_{L}$ decreased because of 


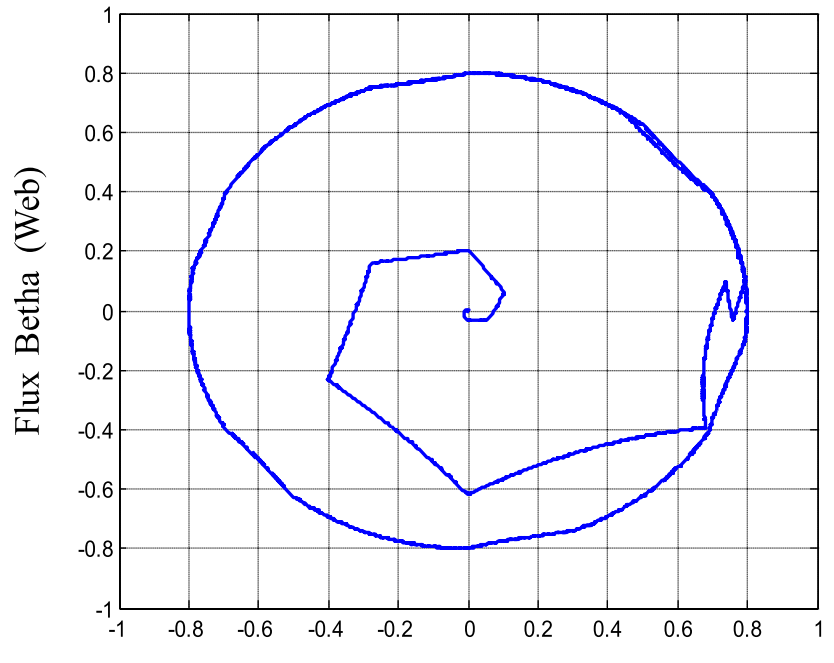

Flux Alpha (Web)

Fig. 16 Flux trajectory

the two inductances restore their energy to the power inverter. In Quasi Z-source, the capacitor voltage has less stress voltage compared with the Z-source topology (Fig. 12) [34-37].

In Fig. 15, the speed response follows its reference.In the induction motor control, direct torque control is used to guarantee an independent control of the flux and the torque. For this, the flux and torque follow well the given references with a high dynamic response (Figs. 14, 16). Moreover, through the DTC the induction motor absorbs a sinusoidal current which illustrates the performance of the developed system as given by Fig. 13 .

It can be noticed that, in both operation modes (boost and DTC), the period of each task should be accurately chosen in order to get high-performance control of the whole system.

\section{Conclusions}

In this paper, an adapted direct torque control of an induction motor fed by a Quasi Z-source inverter has been presented. For this, a switching table is developed to ensure at the same time the induction motor control and the DCLink voltage boost. Hence, the sampling time is divided between the shoot-through states and the direct torque control. Thus, The developed control reduces the boost floor and therefore the number of power switches. Finally, the validation results have been carried out to prove the effectiveness of the developed control.

\section{Compliance with ethical standards}

Conflict of interest The authors declare that they have no conflict of interest.

\section{Appendix}

\section{Rated data of the simulated induction motor}

$\mathrm{P}=4 \mathrm{~kW}, \mathrm{n}=1420 \mathrm{rpm}, \mathrm{p}=2$.

$\mathrm{Rs}=1.823 \Omega, \mathrm{Rr}=3.2422 \Omega, \mathrm{Ls}=0.2289 \mathrm{H}, \mathrm{Lr}=0.2289 \mathrm{H}$, $\mathrm{Lm}=0.2198 \mathrm{H}, \mathrm{J}=4.1587 .10-3 \mathrm{~kg} \cdot \mathrm{m}^{2}, \mathrm{kf}=1.277 \times 10^{-3} \mathrm{Nms} /$ rd.

\section{Impedance network parameters.}

$V_{d c}=100 \mathrm{~V}, \mathrm{~L}=3.2 \mathrm{mH}, \mathrm{C}=1200 \mathrm{e}-3 \mathrm{~F}, \mathrm{r}=1 \Omega$.

\section{References}

1. Peng FZ (2003) Z-source inverter. IEEE Trans Ind Appl 39(2):504-510

2. Peng FZ, Shen M, Qian Z (2005) Maximum boost control of the Z-source inverter. IEEE Trans Power Electron 20(4):833-838

3. Mohr M, Franke W, Wittig B, Fuchs F (2010) Converter systems for fuel cells in the medium power range: a comparative study. IEEE Trans Ind Electron 57(6):2024-2032

4. Abdelhakim A, Mattavelli P, Davari P, Blaabjerg F (2018) Performance evaluation of the single-phase split-source inverter using an alternative dc-ac configuration. IEEE Trans Ind Electron 65(1):363-373

5. Huang $Y$, Shen M, Peng FZ, Wang J (2006) Z-source inverter for residential photovoltaic systems. IEEE Trans Power Electron 21(6):1776-1782

6. Sabeur N, Mekhilef S, Nakaoka M, Masaoud A (2016) A simple modulation based maximum boost control strategy for threephase quasi $Z$-source inverter. In: Proceedings of the 8th IEEE international power electronics and motion control (IPEMCECCE Asia), 22-26 May 2016

7. Thangaprakash S (2009) Modified space vector pulse width modulation for Z-source inverters. Int J Recent Trends Eng 2(6):136-138

8. Barathy B, Kavitha A, Viswanathan T (2014) Effective space vector modulation switching sequence for three-phase $Z$ source inverters. IET Power Electron 7(11):2695-2703

9. Nguyen M, Cheol Lim Y, Park S (2015) A comparison between single-phase Quasi Z-source and Quasi-switched boost inverters. IEEE Trans Ind Electron 62:6336-6344

10. Mohammadi M, Moghani Javad S, Milimonfared J (2018) A novel dual switching frequency modulation for Z-source and Quasi Z-source inverters. IEEE Trans Ind Electron 65:5167-5176

11. Ayad Ayman, Kennel R (2017) A comparison of Quasi-Z source inverters and conventional two-stage inverters for PV applications. EPE J 27:43-59

12. Korkman $Y$, Korzman $F$ (2014) Comparing of switching frequency on vector controlled asynchronous motor. Int J Soft Comput Artif Intell Appl 3:19-27 
13. Ellabban O, Abu-Rub H (2016) Z-source inverter: topology improvements review. IEEE Ind Electron Mag 10(1):6-24

14. Ellabban O, Van Mierlo J, Lataire P (2011) Z-source inverter for vehicular applications. In: IEEE vehicle power and propulsion conference, 6-9 Sept 2011

15. Siwakoti YP, Peng FZ, Blaabjerg F, Loh PC, Town GE, Yang $S$ (2015) Impedance-source networks for electric power conversion, part II: review of control and modulation techniques. IEEE Trans Power Electron 30(4):1887-1906

16. Siwakoti YP, Peng FZ, Blaabjerg F, Loh PC, Town GE (2015) Impedance-source networks for electric power conversion part I: a topological review. IEEE Trans Power Electron 30(2):699-716

17. El Ouanjli N, Derouich A, El Ghzizal A, Motahhir S, Chebabhi A, El Mourabit Y, Taoussi M (2019) Modern improvement techniques of direct torque control for induction motor drives-a review. Prot Control Mod Power Syst 4:1-12

18. Ning B, Cheng S, Qin Y (2016) Direct torque control of PMSM using sliding mode backstepping control with extended state observer. J Vib Control 24(4):1-14

19. Chaouch Souad, Abdou Latifa, Alaoui Larbi Chrifi, Drid Said (2016) Optimized torque control via backstepping using genetic algorithm of induction motor. Automatika 57(2):379-386

20. El Ouanjli N, Motahhir S, Derouich A, El Ghzizal A, Chebabhi A, Taoussi M (2019) Improved DTC strategy of doubly fed induction motor using fuzzy logic controller. Energy Rep 5:271-279

21. Ahriche A, Kidouche M, Mekhilef S (2014) Robust sensorless sliding mode flux observer for DTC-SVM-based drive with inverter nonlinearity compensation. J Power Electron 14:125-134

22. Depenbrock M (1988) Direct self-control (DSC) of inverter fed induction machine. Trans Power Electron 3:420-429

23. Takahashi I, Noguchi T (1986) A new quick-response and highefficiency control strategy of an induction motor. IEEE Trans Ind Appl 22:820-827

24. Inoue Y, Morimoto S, Sanada M (2012) Comparative study of PMSM drive systems based on current control and direct torque control in flux-weakening control region. IEEE Trans Ind Appl 48:2382-2389

25. Zhang Z, Zhao Y, Qiao W, Qu L (2015) A discrete-time direct torque control for direct-drive PMSG-based wind energy conversion. IEEE Trans Ind Appl 51:3504-3514

26. Kumar RH, Iqbal A, Lenin NC (2018) Review of recent advancements of direct torque control in induction motor drives-a decade of progress. IET Power Electron 11:01-15
27. Beng Foo $\mathrm{GH}$, Zhang $X$ (2016) Constant switching frequency based direct torque control of interior permanent magnet synchronous motors with reduced ripples and fast torque dynamics. IEEE Trans Power Electron 31:6485-6493

28. Tabbache B, Douida S, Benbouzid M, Diallo Demba (2016) Direct torque control of five-leg inverter-dual induction motor powertrain for electric vehicles. Electr Eng 98(1):1-13

29. Pandit Jay K, Aware MV, Nemade Ronak V, Levi Emil (2017) Direct torque control scheme for a six-phase induction motor with reduced torque ripple. IEEE Trans Power Electron 32:7118-7129

30. Sutikno T, Idris NRN, Jidin A (2014) A review of direct torque control of induction motors for sustainable reliability and energyefficient drives. Renew Sustain Energy Rev 32:548-558

31. Shen M, Joseph A, Wang J, Peng Fang Z, Adams DJ (2007) Comparison of traditional inverters and Z-source inverter for fuel cell vehicles. IEEE Trans Power Electron 22(4):1453-1463

32. Ellaban O, Van Mierlo J, Lataire P (2011) Experimental study of the shoot-through boost control methods for the Z-source inverter. EPE J 21:18-29

33. Pham Cong-Thanh, Shen Anwen (2012) A comparison of control methods for Z source inverter. Energy Power Eng 4:187-195

34. Liu HePing, Liu Ping, Zhang YuXin (2013) Design and digital implementation of voltage and current control for the quasi-Zsource converters. IET Power Electron 6:990-998

35. Ellaban O, Van Mierlo J, Lataire P (2010) Control of a high-performance $Z$ source inverter for fuel cell/supercapacitor hybrid electric vehicles. World Electr Veh J 4(3):444-451

36. Chen SZ, Cheung NC, Wong KC, Wu J (2010) Integral slidingmode direct torque control of doubly-fed induction generators under unbalanced grid voltage. IEEE Trans Energy Convers 25(2):356-368

37. Huang Jiacai, Cui Lei, Shi Xinxin (2014) Direct torque control of PMSM based on fractional order sliding mode variable structure and experiment research. Int J Control Autom 7(10):217-232

Publisher's Note Springer Nature remains neutral with regard to jurisdictional claims in published maps and institutional affiliations. 